\title{
Enmiendas de estiércol solarizado en la estabilidad de agregados de un Aridisol cultivado de México*
}

\author{
Solarized manure amendments in aggregate stability \\ of cultivated Aridisol from Mexico
}

\author{
Brenda Flores-Sánchez ${ }^{1}$, Miguel Ángel Segura-Castruita ${ }^{1 \S}$, Manuel Fortis-Hernández ${ }^{1}$, Luime Martínez-Corral ${ }^{2}$, Rogelio \\ Armando Aldaco-Nuncio ${ }^{1}$ y Jorge Arnaldo Orozco-Vidal ${ }^{1}$ \\ ${ }^{1}$ Instituto Tecnológico de Torreón-DEPI. Carretera Torreón-San Pedro, km 7.5. Ejido Anna, Torreón, Coahuila, México. C. P. 27170. Tel: 871 750 7198. (ibq_brenda@ \\ hotmail.com; dmilys5@hotmail.com; fortismanuel@hotmail.com; ppreciador@yahoo.com.mx; joorvi66@hotmail.com).2Instituto Tecnológico Superior de Lerdo-DEPI, \\ Ciudad Lerdo, Durango, México. C. P.31150. (luime_mc18@yahoo.com.mx). ${ }^{\S}$ Autor para correspondencia: dmilys5@hotmail.com.
}

\section{Resumen}

Suelos de regiones áridas reciben enmiendas de estiércol solarizado, pero se desconoce el efecto de éstas sobre la estabilidad de los agregados del suelo. Los objetivos de este trabajo fueron: 1) caracterizar un Aridisol con ocho años de enmiendas de estiércol solarizado; y 2) identificar los factores físicos o químicos que influyen en la estabilidad de sus agregados. Dos sitios con suelos similares fueron seleccionados; uno con enmiendas y otro sin ellas. Pozos pedológicos fueron excavado y se describieron su sitio y perfil; asimismo, se colectaron muestras de sus horizontes para su análisis y caracterización. Análisis físicos y químicos con fines de clasificación fueron realizados a cada muestra. Aparte, muestras de estiércol fueron analizadas, así como, la estabilidad de los agregados del suelo de la capa superficial $(0-30 \mathrm{~cm})$ de cada suelo. Los datos de contenido de arcilla, materia orgánica y carbonatos de calcio, se relacionaron con la estabilidad de agregados para identificar los factores que influye en su estabilidad. Un análisis de varianza de los modelos que se obtuvieron fue realizado, así como una prueba de de medias con Tukey $(p \leq 0.05)$. Los resultados muestran que la estabilidad de los agregados de un Fluventic Haplocambid son diferentes, ya que los suelos con enmiendas tuvieron una estabilidad de agregados (11.6\%) mayor que

\section{Abstract}

Arid soil regions receive solarized manure amendments, but their effect on soil aggregate stability is unknown. The objectives of this study were: 1) characterize an Aridisol with eight years of solarized manure amendments; and 2) identify the physical or chemical factors influencing aggregate stability. Two sites with similar soils were selected; one with amendments and one without them. Trial pits were dug describing place and profile; taking also samples from horizons for analysis and characterization. Physical and chemical analyses were made to each sample to classify them. Besides, manure samples were analyzed, thus soil aggregates stability of the surface layer $(0-30 \mathrm{~cm})$ of each soil sample. Data from clay content, organic matter and calcium carbonates, related to aggregate stability to identify factors influencing their stability. An analysis of variance from the models obtained was conducted, as well as Tukey $(p \leq 0.05)$. The results show that aggregates stability of a Fluventic Haplocambids are different, as soils with amendment had an aggregate stability (11.6\%) higher than those soils without amendment $(8.2 \%)$, such that in the first, organic matter content influenced stability and in the second calcium carbonate content. However, soil aggregates stability was low due to the characteristics of solarized manure.

\footnotetext{
* Recibido: marzo de 2015

Aceptado: julio de 2015
} 
aquellos suelos sin enmiendas (8.2\%), de tal manera que en los primeros el contenido de materia orgánica influyó en la estabilidad y en los segundos el contenido de carbonato de calcio. No obstante, la estabilidad de los agregados del suelo fue baja, debido a las características del estiércol solarizado.

Palabras clave: agricultura orgánica, estructura del suelo, Fluventic Haplocambids, materia orgánica.

\section{Introducción}

La estructura del suelo es uno de los factores que condicionan la fertilidad y productividad de los suelos agrícolas (Bronick y Lal, 2004). En la naturaleza, diferentes tipos de estructura como la granular y migajosa, bloques angulares o subangulares, prismática, columnar y laminar, han sido identificadas. La estructura migajosa, granular y de bloques tienen importancia desde el punto de vista agrícola (Alagöz y Yilmaz, 2009). Uno de los parámetros que se utilizan para medir el grado de desarrollo de la estructura del suelo es la estabilidad de sus agregados. Esta estabilidad depende de factores como textura, materia orgánica, humedad, condiciones climáticas e impacto de las actividades del hombre (Zhang et al., 2013); así como de la cantidad y tipo de agentes cementantes que existan en el suelo, como materia orgánica, óxidos de hierro, carbonatos, arcilla y sílice e incluso microorganismos que pueden acelerar o retardar la descomposición de la materia orgánica (Prieto et al., 2013).

La estabilidad de agregados (EA) es un indicador del desarrollo de la estructura de suelo (Lobo y Pulido, 2006), a su vez indica la calidad y cantidad de materia orgánica que existe en el suelo (Lozano et al., 2011). Sin embargo, el tipo de clima dónde se encuentra un suelo, influye sobre estos agentes; por ejemplo, en un Aridisol de lugares con escasa precipitación, alta evaporación, pobres en materia orgánica, $\mathrm{pH}$ neutros y ricos en carbonatos, los contenidos mineralógicos juegan un papel importante en la agregación del suelo (Bastida et al., 2012). La Región Lagunera, en la parte norte de México, tiene un clima árido. En este lugar, la aplicación de estiércol composteado o solarizado como una enmienda orgánica en los suelos, es una práctica que se ha hecho popular en la última década, pues al año se han aplicado de 80 a $120 \mathrm{tha}^{-1}$ de estiércol solarizado (Fortis et al., 2009).
Keywords: Fluventic Haplocambids, organic farming, organic matter, soil structure.

\section{Introduction}

Soil structure is one of the factors affecting fertility and productivity of agricultural soils (Bronick and Lal, 2004). In nature, different types of structure such as granular and single grained, blocky or sub-angular, prismatic, columnar and layered, have been identified. Single grained, granular and blocky structures are important from the agricultural point of view (Alagöz and Yilmaz, 2009). One of the parameters used to measure the degree of development of soil structure is aggregates stability. This stability depends on factors such as texture, organic matter, moisture, weather conditions and impact of human activities (Zhang et al., 2013); as well as the amount and type of cementing agents that exist in the soil such as organic matter, iron oxides, carbonates, clay and silica and even microorganisms that can accelerate or delay the decomposition of organic matter (Prieto et al., 2013).

Aggregate stability (AE) is an indicator of development of soil structure (Lobo and Pulido, 2006), and at the same time indicates the quality and quantity of organic matter that exists on the soil (Lozano et al., 2011). However, weather conditions, has influence on these agents; for example, on an Aridisol soil with low rainfall, high evaporation, poor organic matter content, $\mathrm{pH}$ neutral and rich in carbonates, mineralogical content play an important role in soil aggregation (Bastida et al., 2012). The Comarca Lagunera, in the northern part of Mexico, has an arid climate. In this place, the application of composted or solarized manure as an organic amendment on the soil, is a practice that has become popular in the last decade, as for the year have been applied from 80 to $120 \mathrm{t} \mathrm{ha}^{-1}$ of solarized manure (Fortis et al., 2009).

Solarized manure receives a treatment known as solarization, where the heat generated by sunlight during the process removes pathogenic microorganisms present in the material (Ruiz, 2011). This type of amendment is an alternative for farmers to the growing demand for organic food (Garcia et al., 2009). Trejo et al. (2013) used this type of material and concluded that it is an excellent option for meeting crop nutrient demand. Moreover, solarized manure as organic fertilizer has been used to produce cotton in highdensities, where fiberquality and yield was evaluated, as well as soil temperature (Lopez et al., 2014). 
El estiércol solarizado recibe un tratamiento que se conoce como solarización, donde el calor que generan los rayos solares durante el proceso elimina microorganismos patógenos presentes en el material (Ruiz, 2011). Este tipo de enmienda representa una alternativa para los productores agrícolas ante la creciente demanda de alimentos orgánicos (García et al., 2009). Trejo et al.(2013) utilizaron este tipo de material y concluyeron que es una excelente opción para satisfacer la demanda nutrimental de cultivos. Por otra parte, el estiércol solarizado como enmienda orgánica se ha utilizado para la producción de algodón en altas densidades, donde se evaluó la calidad de la fibra y rendimiento, así como la temperatura del suelo (López et al., 2014). No obstante, el conocimiento del efecto del estiércol solarizado sobre las propiedades físicas del suelo como la formación de agregados y su estabilidad en los suelos de regiones áridas es escaso (Arroita et al., 2013).

Es probable que al determinar el efecto positivo de la aplicación del estiércol solarizado en la estabilidad de los agregados en suelos de regiones áridas, se establezca su utilización en estas regiones. Por lo anterior, los objetivos de esta investigación fueron 1) caracterizar un Aridisol del norte de México con ocho años de aplicaciones de enmiendas con estiércol solarizado; y 2) Identificar los factores físicos o químicos que influyen en la estabilidad de los agregados en este suelo.

\section{Materiales y métodos}

\section{Área de estudio}

El área de estudio se localizó en el "Ejido El Fresno del Norte", municipio de Francisco I. Madero, Coahuila; ubicado en la carretera Torreón-San Pedro km 37.5. Se localiza de $\operatorname{los} 25^{\circ} 44.89^{\prime}$ a $25^{\circ} 44.9^{\prime}$ latitud norte y de $\operatorname{los} 103^{\circ} 17.7^{\prime}$ a $103^{\circ} 17.8^{\prime}$ ' longitud oeste, a $1120 \mathrm{msnm}$ (Figura 1). Este sitio se seleccionó porque a sus suelos se han agregado enmiendas orgánicas con estiércol solarizado (80 t ha-1) durante ocho años (Hernández et al., 2013). El clima es un Bw (h') hw (e), seco o estepario cálido, con un régimen de lluvias en verano e inviernos fríos. La precipitación total anual es de $238 \mathrm{~mm}$; con una temperatura media anual de $21^{\circ} \mathrm{C}$, con rangos de $37^{\circ} \mathrm{C}$ como máxima y mínima de $7.5^{\circ} \mathrm{C}$, la evaporación media total anual es de $2000 \mathrm{~mm}$ (García, 1988).
However, knowledge of the effect of solarized manure on soil physical properties as aggregate formation and in soil stability of arid regions is scarce (Arroita et al., 2013).

It is likely that by determining the positive effect of the application of solarized manure in soil aggregate stability of arid regions, its use will be established in these regions. Therefore, the objectives of this study were 1) to characterize anAridisol from northern Mexico with eight years of solarized manure amendments application; and 2) identify the physical or chemical factors influencing on soil aggregates stability.

\section{Materials and methods}

\section{Study area}

The study area was located in the "Ejido El Fresno del Norte", municipality of Francisco I. Madero, Coahuila; located in Torreon-San Pedro $37.5 \mathrm{~km}$ road. It is located $25^{\circ} 44.89^{\prime}$ at $25^{\circ}$ $44.9^{\prime}$ north latitude and $103^{\circ} 17.7^{\prime}$ to $103^{\circ} 17.8^{\prime}$ west longitude, at 1120 masl (Figure 1). This site was selected because on this soil has been applied organic amendments with solarized manure (80 t ha-1) for eight years (Hernández et al., 2013). Climate is Bw (h') hw (e), dry or warm steppe, with rainfall in summer and cold winters. Total annual precipitation is 238 $\mathrm{mm}$; with an average annual temperature of $21^{\circ} \mathrm{C}$, with ranges of $37^{\circ} \mathrm{C}$ as maximum and $7.5^{\circ} \mathrm{C}$ minimum, the mean total annual evaporation is $2000 \mathrm{~mm}$ (García, 1988).

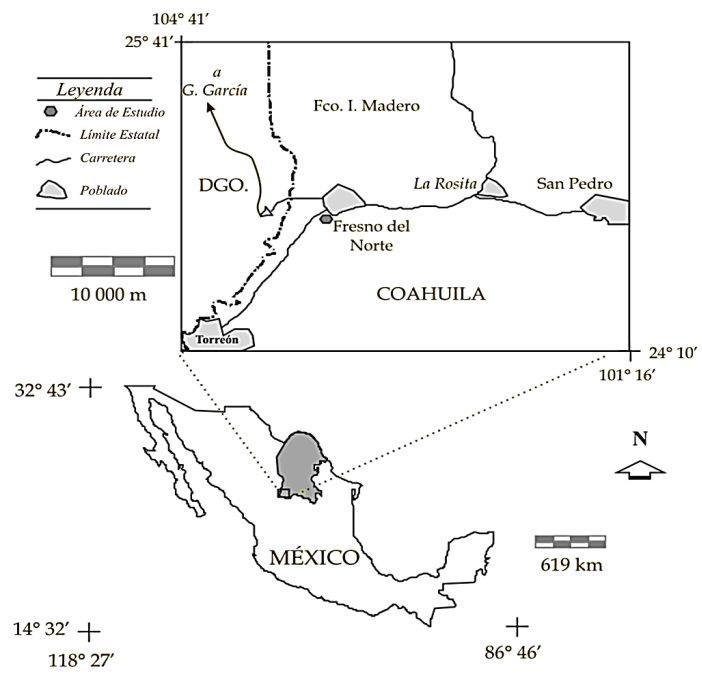

Figura 1. Localización del área de estudio ejido Fresno del Norte, Coahuila, México.

Figure 1. Location of the study area ejido Fresno del Norte, Coahuila, Mexico. 


\section{Métodos}

El estudio se dividió en cuatro etapas, 1) caracterización del suelo delárea de estudio y su clasificación; 2) análisis físicoy químico del estiércol solarizado que se ha agregado al suelo; 3) evaluación de la estabilidad de agregados; y4) análisis de los resultados. A continuación se describe la metodología:

Caracterización del suelo del área de estudio y su clasificación. Dos sitios con el mismo suelo en el área de estudio fueron seleccionados; un suelo con enmiendas $(\mathrm{Se})$ y otro sin enmiendas $(S s)$. Los suelos fueron caracterizados mediante la excavación de un pozo pedológico en cada uno de los sitios para determinar sus propiedades y características con el fin de establecer la igualdad de los suelos. El perfil de cada pozo fue descrito siguiendo el Manual de la Soil Survey Field and Laboratory Methods Manual (SSI, 2009). Muestras de suelo de los horizontes de cada perfil fueron colectadas (dos kg, aproximadamente) y trasladadas a laboratorio para llevar a cabo diferentes análisis físicos y químicos. Las muestras fueron secadas a temperatura ambiente y a la sombra.

Una vez secas las muestras de suelo, fueron molidas y tamizadas en una malla de dos milímetros de diámetro, entonces se procedió a la determinación de las propiedades físicas y químicas siguientes: color en seco y en húmedo (tabla de colores de Munsell), densidad aparente(Da, método de la parafina), reacción del suelo (pH en agua relación 2:1), materia orgánica ( $\mathrm{MO}$, método de Walkley y Black), análisis del tamaño de partículas (método de la pipeta), capacidad de intercambio catiónicoy cationes intercambiables (CIC, método del acetato de amonio pH 71N), conductividad eléctrica(CE) y cationes solubles (extracto de la pasta de saturación), pentóxido de fósforo (método del ácido cítrico), determinaciones que se especifican en el Manual de Van Reeuwijk (2006), con fines de clasificación. Las determinaciones se realizaron por triplicado. Cuando se tuvieron los datos de laboratorio y con la información de campo, se procedió a realizar la clasificación de los suelos mediante el sistema de clasificación Taxonomía de Suelos (SSS, 2014).

Análisis físico y químico del estiércol solarizado. Cinco submuestras de estiércol solarizado del establo Fresno del Norte fueron colectadas; este material se utiliza como enmienda orgánica en las parcelas de los campesinos del ejido. Las muestras fueron llevadas al laboratorio, donde se tomó una pequeña muestra para obtener la humedad gravimétrica al momento del muestreo, posteriormente se

\section{Methods}

The study was divided into four stages: 1) soil characterization of the study area and its classification; 2) physical and chemical analyses of solarized manure that has been added to the soil; 3) evaluation of aggregate stability; and 4) analyze the results. The methodology is described as follows:

Soil characterization of the study area and its classification. Two sites with the same soil in the study area were selected; a soil with amendment $(\mathrm{Se})$ and one without amendments (Ss). The soils were characterized through a trial pit in each of the sites to determine their properties and characteristics in order to establish equality of the soils. The profile of each pit was described following the Soil Survey Field and Laboratory Methods Manual (SSI, 2009). Soil samples of horizons from each profile were collected (two $\mathrm{kg}$, approximately) and taken to laboratory to perform different physical and chemical analysis. The samples were dried at room temperature and under shade.

Once soil samples are dried, this were milled and sieved in a two millimeters diameter mesh, then proceeded to the determination of the following physical and chemical properties: dry and wet soil color (Munsell color chart), bulk density (Da, paraffin method), soil reaction ( $\mathrm{pH}$ water 2 : 1 ratio), organic matter (OM, Walkley and Black method), particle size analysis (pipette method), interchangeability and cationic exchangeable cations (CIC, ammonium acetate method $1 \mathrm{~N} \mathrm{pH} \mathrm{7),} \mathrm{electrical} \mathrm{conductivity} \mathrm{(CE)} \mathrm{and} \mathrm{soluble}$ cations (saturation paste extract), phosphorus pentoxide (citric acid method), determinations specified in the Van Reeuwijk Manual (2006), for classification purposes. The determinations were performed in triplicate. When laboratory data and field data were taken, proceeded to perform soil classification by Soil Taxonomy System (SSS, 2014).

Physical and chemical analysis of solarized manure. Five sub-samples of solarized manure from the stable Fresno del Norte were collected; this material is used as organic fertilizer in farmers' fields. Samples were taken to the laboratory, where a small sample was taken for gravimetric moisture at the time of sampling, then were dried under shade for $48 \mathrm{~h}$. Once the samples were dry, were mixed to generate a composite sample, which was subjected to different analysis. The physical and chemical analyzes were to determine the $\mathrm{Da}$, moisture, total nitrogen $(\mathrm{N}, \mathrm{Kjeldahl}$ method); and the percentage of OM to obtain the percentage of total carbon $(\mathrm{C}$, wet combustion method Walkley and 
sometieron a secado a la sombra durante $48 \mathrm{~h}$. Una vez que las muestras estuvieron secas, se mezclaron para generar una muestra compuesta, la cual se sometió a diferentes análisis de laboratorio. Los análisis físicos y químicos consistieron en determinar la $\mathrm{Da}$, humedad, nitrógeno total $(\mathrm{N}$, método de Kjeldhal); así como el porcentaje de MO para obtener el porcentaje de carbono total $(\mathrm{C}$, método de combustión húmeda Walkley y Black), como se indica en el Manual de Van Reeuwijk (2006), con el fin de conocer el modo cómo influyen estas características en la estabilidad de los agregados. Además se estimó la relación $\mathrm{C} / \mathrm{N}$, como se establece en el Manual del CTNNPAP (2007).

Evaluación de la estabilidad de agregados. En un muestreo aparte, se colectaron cinco muestras de suelo de la capa superficial $(0-30 \mathrm{~cm}$ de profundidad), que estuvieron distribuidas aleatoriamente en una hectárea, de cada uno de los sitios de los suelos en estudio ( $\mathrm{Se} \mathrm{y} S s$ ), teniendo especial cuidado en no destruir los agregados de los suelos. Las muestras se sometieron a secado a temperatura ambiente y a la sombra. Cuando las muestras de suelo estuvieron secas, la determinación de la estabilidad de los agregados se llevó a cabo, con la ecuación 1(SSI, 2009).

$\mathrm{AE}_{\mathrm{m}>0.25}=\frac{\mathrm{WAs}-a}{\mathrm{WSd}-a} \times 100$

Donde: $\mathrm{AE}_{\mathrm{m}>0.25}=$ agregados estables al agua a un diámetro menor que $0.25 \mathrm{~mm}$; WAs= peso de los agregados secos; $\mathrm{WSd}=$ peso del suelo seco; $a=$ peso de las arenas.

Asimismo, a cada muestra se le determinó el contenido de MO por el método de combustión húmeda (Walkley y Black), arcilla (r) mediante el método de la pipeta y carbonatos de calcio $\left(\mathrm{CaCO}_{3}\right)$ por el desplazamiento de gas, como se especifica en el Manual de Van Reeuwijk (2006), con el fin de determinar cuál de estas características influyen en la estabilidad de los agregados de estos suelos.

Análisis de los resultados. Los resultados de estabilidad de agregados del suelo con y sin enmienda, se analizaron estadísticamente mediante una comparación de medias de Tukey ( $p \leq 0.05)$; aparte los datos de estabilidad se relacionaron con los parámetros porcentaje de arcilla, contenido de materia orgánica y carbonatos de calcio equivalentes, para determinar el efecto de éstos agentes aglutinantes en la estabilidad de los agregados. El análisis se realizó en el programa Minitab 16 (Minitab, 2013).
Black), as indicated in the Van Reeuwijk Manual (2006), in order to know how these characteristics affect aggregate stability. Furthermore the $\mathrm{C} / \mathrm{N}$ ratio was estimated as stated in the CTNNPAP (2007) Manual.

Evaluation of aggregate stability. In a separate sampling, five soil samples were taken from the surface layer (0-30 $\mathrm{cm}$ depth), which were randomly distributed in one hectare from each of the study sites ( $S e$ and $S s$ ), having special care not to destroy soil aggregates. The samples were dried at room temperature and under shade. When soil samples were dry, aggregate stability was conducted with Equation 1 (SSI, 2009).

$\mathrm{AE}_{\mathrm{m}>0.25}=\frac{\text { WAs }-a}{\mathrm{WSd}-a} \times 100$

Where: $\mathrm{AE}_{\mathrm{m}>0.25}=$ water stable aggregates to a diameter less than $0.25 \mathrm{~mm}$; $\mathrm{WA}_{\mathrm{s}}=$ the weight of dry aggregates; $\mathrm{WSd}=$ the weight of dry soil; $a$ it is the weight of the sand.

Also, to each sample was determined the content of OM by the wet combustion method (Walkley and Black), clay (r) pipette method and calcium carbonate $\left(\mathrm{CaCO}_{3}\right)$ gas displacement, as specified in Van Reeuwijk Manual (2006), in order to determine which of these characteristics affect aggregates stability of these soils.

Analysis of results. The results of soil aggregate stability with and without amendment were statistically analyzed by mean comparison of Tukey ( $p \leq 0.05)$; besides stability data were related to the parameters, percentage of clay, organic matter and equivalent calcium carbonates, to determine the effect of these cementing agents in aggregate stability. The analysis was performed in Minitab 16 (Minitab, 2013).

\section{Results and discussion}

\section{Soil characteristics of study site}

The soils are made up of six or seven mineral soil horizons (Table 1), whose transition is horizontal and marked due to changes in texture and structure. There were no indications of pedogenic processes; that is, according to Hernandez et al. (2013), an indicative of scarce or no soil development. Generally speaking, the surface layer of these soils has 


\section{Resultados y discusión}

\section{Características de los suelos en estudio}

Los suelos están formados por seis o siete horizontes de suelo mineral (Cuadro 1), cuya transición es horizontal y marcada, debido a los cambios en textura y estructura. No se detectaron indicios de procesos pedogenéticos; lo que es, de acuerdo con Hernández et al. (2013), indicativo de un escaso o nulo desarrollo del suelo. En términos generales, la capa superficial de estos suelos presenta colores pardos 10YR 6/3 en seco y de pardo amarillentos 10 YR $4 / 4$ a pardo grisáceo oscuro 10YR 4/2 en húmedo. El color puede ser influenciado por el material parental y las condiciones de aridez que prevalecen en la zona de estudio.

Estos suelos presentan texturas medias, cuentan con macroporos y microporos, por lo que tienen un buen drenaje y se mantienen aireados (Verdonk y Demeyer, 2004). La ausencia de manganesoy motas dehierro en todo el espesor de los perfiles confirma lo anterior. Algunos horizontes tuvieron una reacción fuerte y rápida, después de adicionar $\mathrm{HCl}$ en cada uno de ellos. Asimismo, la presencia de raíces hasta una profundidad mayor que $100 \mathrm{~cm}$ de profundidad, es indicativo de las buenas condiciones de porosidad y aireación de estos suelos; lo que favorece el desarrollo radicular de las plantas (Huang et al., 2011). Una secuencia de horizontes (Ap, A, C, $\mathrm{C}_{2}, 2 \mathrm{C}, 3 \mathrm{C}$ ) fue identificada en estos suelos, lo que refleja las continuidades y discontinuidades litológicas de los mismos; es decir, se formó de diferentes eventos de sedimentación. Los suelos, a pesar de haberse descrito en dos puntos diferentes del ejido (área de parcelas), pueden ser considerados morfológicamente similares. La Da de estos suelos varía en un rango de $1.21 \mathrm{a} 1.53 \mathrm{~g} \mathrm{~cm}^{-3}$, valores que se encuentran dentro del intervalo de suelos no compactados; que corresponden a suelos con textura franca finas y arenosas (Porta et al., 2010).

Los contenidos de MO fueron bajos (0.54 - 1.98\%) y decrecen irregularmente con la profundidad. De acuerdo con los contenidos establecidos por Huang et al. (2011) para MO en el suelo, los valores que se encontraron en esta investigación son pobres, lo cual refleja la escasa o nula aplicación de este material en forma de estiércol o abonos; resultado que no corresponde a lo esperado al considerar que a estos suelos se les ha agregado estiércol solarizado durante ocho años . La capacidad de intercambio catiónico (CIC) promedio fue de 20 meq $100 \mathrm{~g}^{-1}$, que se puede considerar como media de acuerdo con Porta et al. (2010). El catión brown colors 10YR 6/3 in dry and yellowish brown $4 / 4$ 10YR to dark grayish brown 10 YR $4 / 2$ in wet. Color can be influenced by parent material and arid conditions prevailing in the study area.

These soils have medium texture, have macropores and micropores, so they have good drainage and maintain aerated (Verdonk and Demeyer, 2004). The absence of manganese and iron spots throughout the thickness of the profiles confirms this. Some horizons had a strong and rapid reaction, after adding $\mathrm{HCl}$ in each. Also, the presence of roots to a depth higher than $100 \mathrm{~cm}$ is indicative of good porosity and aeration conditions of these soils; favoring root development (Huang et al., 2011). A horizons sequence (Ap, A, C, $\mathrm{C}_{2}, 2 \mathrm{C}, 3 \mathrm{C}$ ) was identified in these soils, reflecting the lithological continuities and discontinuities thereof; that is, it formed from different sedimentation events. Soil, despite being described at two different points from the ejido (plot area), can be considered morphologically similar. Da of the soil varies in a range of 1.21 to $1.53 \mathrm{~g} \mathrm{~cm}^{-3}$, values within the range of non-compacted soils; corresponding to soils with fine sandy loam textures (Porta et al., 2010).

OM contents were low $(0.54-1.98 \%)$ and decreases irregularly with depth. In accordance with the contents set by Huang et al. (2011) for OM on the soil, the values found in this research are poor, reflecting scarce or no application of this material in the form of manure; result that does not correspond to expectations considering that these soils have been added solarized manure for eight years. The average cation exchange capacity (CIC) was 20 meq 100 $\mathrm{g}^{-1}$, which can be considered as average according to Porta et al. (2010). The most abundant cation in these soils was calcium (11.82 to 20.17 meq $100 \mathrm{~g} \mathrm{~g}^{-1}$ ), while magnesium (1.01 to $\left.1.83 \mathrm{meq} 100 \mathrm{~g}^{-1}\right)$, potassium $(0.84$ to $2.18 \mathrm{meq}$ $\left.100 \mathrm{~g}^{-1}\right)$ and sodium ( 0.96 to 2.25 meq $\left.100 \mathrm{~g}^{-1}\right)$ were found in lower amounts.

Base saturation of these soils was greater than $50 \%$. This is associated to the low number of charges that these soils presented and rapidly saturates with the few cations present. Analyzing the data and considering that the moisture regime of these soils was aridic and hyperthermic temperature regime, soils were classified as a Fluventic Haplocambids; name indicating that are soils from arid climates (Aridisol) counting with a normal horizon sequence, with diagnostic characteristics that suggest the development of color or structure resembling to Entisols or 
más abundante en estos suelos fue el calcio (11.82 a 20.17 meq $\left.100 \mathrm{~g} \mathrm{~g}^{-1}\right)$, mientras que, el magnesio (1.01 a $1.83 \mathrm{meq}$ $\left.100 \mathrm{~g}^{-1}\right)$, el potasio $\left(0.84 \mathrm{a} 2.18 \mathrm{meq}^{100 \mathrm{~g}^{-1}}\right)$ y el sodio $(0.96$ a 2.25 meq $100 \mathrm{~g}^{-1}$ ) se encontraron en cantidades bajas. soils showing no evidence of horizons diagnosis, formed by river currents or different sedimentation events from soil materials (SSS, 2014). The way soil is formed and climate are important factors, preventing the accumulation

Cuadro 1. Características físicas y químicas de los suelos sin enmiendas y con enmiendas del ejido Fresno del Norte, México Table 1.Physical and chemical characteristics of the soils without and with amendments from the ejido Fresnodel Norte, Mexico.

\begin{tabular}{|c|c|c|c|c|c|c|c|c|c|c|c|c|c|}
\hline \multirow[t]{2}{*}{ Suelo } & \multirow[t]{2}{*}{ Hte. } & \multirow{2}{*}{$\begin{array}{l}\text { Prof. } \\
(\mathrm{cm})\end{array}$} & \multicolumn{2}{|c|}{ Color } & \multirow{2}{*}{$\begin{array}{c}A \\
(\%)\end{array}$} & \multirow{2}{*}{$\begin{array}{c}1 \\
(\%)\end{array}$} & \multirow{2}{*}{$\begin{array}{c}\mathrm{R} \\
(\%)\end{array}$} & \multirow{2}{*}{$\begin{array}{l}\text { MO } \\
(\%)\end{array}$} & \multirow{2}{*}{$\begin{array}{c}\mathrm{CaCO}_{3} \\
(\%)\end{array}$} & \multirow[t]{2}{*}{$\mathrm{pH}$} & \multirow{2}{*}{$\begin{array}{c}\mathrm{Da} \\
\left(\mathrm{g} \mathrm{cm}^{-3}\right)\end{array}$} & \multirow{2}{*}{ 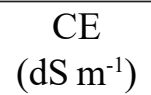 } & \multirow{2}{*}{$\begin{array}{l}\mathrm{P}_{2} \mathrm{O}_{5} \\
(\mathrm{ppm})\end{array}$} \\
\hline & & & Seco & Húmedo & & & & & & & & & \\
\hline \multirow[t]{17}{*}{$S s^{*}$} & Ap & $0-11$ & 10YR6/3 & 10YR3/3 & 38.1 & 43.2 & 18.7 & 0.70 & 11.6 & 8.1 & 1.53 & 1.94 & 137 \\
\hline & A & $11-28$ & $10 \mathrm{YR} 6 / 3$ & $10 Y$ & 40.2 & 40.9 & 18.9 & 0.62 & 11.2 & 7.9 & 1.50 & 0.45 & 135 \\
\hline & $\mathrm{C}$ & $28-45$ & 10YR6/4 & $/ 2$ & 36.3 & 35.9 & 27.8 & 0.54 & 10.5 & 7.8 & 1.5 & 1.15 & 123 \\
\hline & $\mathrm{C}_{2}$ & $45-66$ & 10YR6/4 & $10 \mathrm{YR} 4 / 3$ & 36.7 & 36.6 & 26.7 & 1.18 & 10 & 7.8 & 1.2 & 0.53 & 127 \\
\hline & $2 \mathrm{C}$ & $67-88$ & 10YR6/3 & 10YR4/2 & 40.5 & 29.8 & 29.7 & 0.44 & 8.3 & 7.4 & 1.35 & 1.18 & 119 \\
\hline & $3 \mathrm{C}$ & $88-102$ & 10YR6/3 & 10YR3/3 & 42.1 & 39.6 & 18.3 & 0.73 & 10.1 & 7.8 & 1.48 & 1.18 & 113 \\
\hline & $4 \mathrm{C}$ & $>102$ & 10YR6/3 & 10YR3/3 & 32.1 & 52.6 & 20.5 & 0.98 & 11.2 & 8.0 & 1.25 & 1.18 & 215 \\
\hline & Hte. & $\mathrm{Ca}$ & $\mathrm{Mg}$ & K & $\mathrm{Na}$ & CIC & PSI & RAS & $\mathrm{Ca}$ & $\mathrm{Mg}$ & K & $\mathrm{Na}$ & PSB \\
\hline & & (meq & (meq & (meq & (meq & (meq & $(\%)$ & & (meq L- & nor I- & (meq L-1) & $\left(\mathrm{meq} \mathrm{L}^{-1}\right)$ & $(\%)$ \\
\hline & & $\left.100 \mathrm{~g}^{-1}\right)$ & $\left.100 \mathrm{~g}^{-1}\right)$ & $\left.100 \mathrm{~g}^{-1}\right)$ & $\left.100 \mathrm{~g}^{-1}\right)$ & $\left.100 \mathrm{~g}^{-1}\right)$ & & & & & & & \\
\hline & Ap & 15.64 & 1.82 & 1.10 & 0.97 & 20.3 & 4.77 & 0.32 & 4.38 & 0.49 & 1.13 & 0.24 & 96.2 \\
\hline & A & 17.25 & 80 & & 1.00 & 19.9 & 5.26 & 0.32 & 5.4 & & 0.88 & 1.29 & 100 \\
\hline & $\mathrm{C}$ & 20.17 & 1.17 & & 0.98 & 21.3 & 4.60 & 0.30 & 4.71 & 0.46 & 0.47 & 2.05 & 100 \\
\hline & $\mathrm{C}_{2}$ & 11.84 & & & 2.25 & 20.5 & 10.97 & 0.87 & 3.8 & 0.41 & 0.47 & 2.28 & 85.5 \\
\hline & $2 \mathrm{C}$ & 19.51 & 1.03 & & 0.96 & 17.6 & 5.45 & 0.29 & 2.48 & 0.26 & 0.41 & 1.85 & 100 \\
\hline & $3 \mathrm{C}$ & 13.27 & & & 0.96 & 18.7 & 5.13 & 0.34 & 5.5 & 56 & 0.64 & 3.14 & 97.1 \\
\hline & $4 \mathrm{C}$ & 11.92 & & 0.98 & 2.09 & 21.7 & 9.63 & 0.82 & 4.43 & 0.61 & 0.51 & 3.70 & 73.7 \\
\hline \multirow[t]{16}{*}{$\mathrm{Se}$} & Hte. & Prof. & \multicolumn{2}{|c|}{ Color } & A & 1 & $\mathrm{R}$ & MO & $\mathrm{CaCO}_{3}$ & $\mathrm{pH}$ & $\mathrm{Da}$ & $\mathrm{CE}$ & $\mathrm{P}_{2} \mathrm{O}_{5}$ \\
\hline & & $(\mathrm{cm})$ & Seco & Húmedo & $(\%)$ & $(\%)$ & $(\%)$ & $(\%)$ & $(\%)$ & & $\left(\mathrm{g} \mathrm{cm}^{-3}\right)$ & $\left(\mathrm{dS} \mathrm{m}^{-1}\right)$ & (nnm) \\
\hline & Ap & $0-18$ & 10YR6/3 & & 37.8 & 43.2 & 19.0 & 1.80 & 7.6 & 8.0 & 1.44 & 1.98 & 183 \\
\hline & A & -29 & YR6/4 & & 9.9 & 40.3 & 19.8 & 1.92 & 8. & & 1.3 & 0.44 & 169 \\
\hline & $\mathrm{C}$ & $29-56$ & 10YR6/4 & 10YR4/2 & 31.1 & 43.2 & 25.7 & 0.63 & 7.7 & 7.6 & 1.26 & 1.13 & 146 \\
\hline & $2 \mathrm{C}$ & $56-72$ & 10YR6/3 & & 40.1 & 45.6 & 14.3 & 0.87 & 10. & 7.8 & 1.50 & 0.66 & 137 \\
\hline & $2 \mathrm{C}_{2}$ & $72-110$ & 10YR6/4 & $10 \mathrm{YR}$ & 36.0 & 49.9 & 14.1 & 0.44 & 11.1 & 7.9 & 1.48 & 1.21 & 119 \\
\hline & $3 \mathrm{C}$ & $>110$ & $10 \mathrm{YR} 6 / 3$ & 10YR3/2 & 48.8 & 34.5 & 16.7 & 0.52 & 10.6 & 7.8 & 1.22 & 1.17 & 204 \\
\hline & Hte. & $\mathrm{Ca}$ & $\mathrm{Mg}$ & K & $\mathrm{Na}$ & CIC & PSI & RAS & $\mathrm{Ca}$ & $\mathrm{Mg}$ & K & $\mathrm{Na}$ & PSB \\
\hline & & $\begin{array}{c}\text { (meq } \\
\left.100 \mathrm{~g}^{-1}\right)\end{array}$ & $\begin{array}{c}\text { (meq } \\
\left.100 \mathrm{~g}^{-1}\right)\end{array}$ & $\begin{array}{c}\text { (meq } \\
\left.100 \mathrm{~g}^{-1}\right)\end{array}$ & $\begin{array}{c}\text { (meq } \\
\left.100 \mathrm{~g}^{-1}\right)\end{array}$ & $\begin{array}{c}\text { (meq } \\
\left.100 \mathrm{~g}^{-1}\right)\end{array}$ & $(\%)$ & & & & & & \\
\hline & Ap & 16.43 & & & 1.11 & 22.1 & 5.02 & 0.99 & 4.3 & & 1.1 & 0.24 & 92.7 \\
\hline & A & .27 & & & & 21.7 & 5.29 & 1.02 & 5.4 & & 0.8 & 1.29 & 100 \\
\hline & $\mathrm{C}$ & .31 & 16 & & 0.96 & 22.8 & 4.21 & 0.85 & 4.71 & & 0.47 & 2.05 & 98.4 \\
\hline & $2 \mathrm{C}$ & 13.48 & & & & 17.8 & 11.96 & 1.92 & & & 0.47 & 2.28 & 100 \\
\hline & $2 \mathrm{C}_{2}$ & & & & & & 6.54 & 0.99 & 2.4 & & 0.41 & 1.85 & 100 \\
\hline & $3 \mathrm{C}$ & 14.33 & 1.69 & 0.84 & 2.10 & 18.4 & 11.41 & 1.89 & 5.55 & 0.66 & 0.64 & 3.14 & 100 \\
\hline
\end{tabular}

* $S S=$ suelo sin enmienda; $S$ : suelo con enmienda; Hte: horizonte; Prof.: profundidad; a: arena; $1=$ limo; $\mathrm{r}=$ arcilla; PSI= porcentaje de sodio intercambiable; RAS= relación de adsorción de sodio; $\mathrm{PSB}=$ porcentaje de saturación de bases.

La saturación de bases de estos suelos fue mayor que $50 \%$. Lo anterior está relacionado con el bajo número de cargas que estos suelos presentaron y que se saturan rápidamente con of organic matter naturally; such that the clay fraction (silicate and calcium carbonate) of the surface layer may play an important role in soil stability. 
los pocos cationes presentes. Al analizar los datos obtenidos $\mathrm{y}$ al considerar que el régimen de humedad de estos suelos fue arídico y con régimen de temperatura hipertérmico, los suelos se clasificaron como un Fluventic haplocambids; nombre que indica que se tratan de un suelos de climas áridos (Aridisol) que tiene una secuencia normal de horizontes, con características de diagnóstico que sugieren el desarrollo de color o estructura y que se parecen a Entisols o suelos que no muestran evidencias de horizontes de diagnóstico, formados por corrientes de ríos o diferentes eventos de sedimentación de materiales edáficos (SSS, 2014). El modo de formación del suelo y el clima son factores importantes, que no permiten la acumulación de materia orgánica de manera natural; de tal manera que la fracción arcilla (silicatada y carbonatos de calcio) de la capa superficial podrían jugar un papel importante en la estabilidad del suelo.

\section{Características del estiércol solarizado}

El estiércol solarizado tuvo una Da menor que $1 \mathrm{~g} \mathrm{~cm}^{-3}$, lo que refleja que el volumen que ocupa su espacio de vacío es mayor que su masa, mientras que por su $\mathrm{pH}$ (alcalino) y CE (Cuadro 2); puede considerase como salino(CNNPAP, 2007).

Este material presentó una relación $\mathrm{C} / \mathrm{N}$ de 20.3 , resultado mayor que el valor 18 , que ha sido reportado para el estiércol bovino fresco (CNNPAP, 2007). Mientras que el nitrógeno total fue $0.83 \%$, dato menor que $1.70 \%$ que se ha reportado para el estiércol (Domínguez, 2009). El estiércol solarizado es el estiércol que se ha sometido a calentamiento con ayuda de una cubierta plástica, con el fin de eliminar patógenos; sin embargo, no se inicia ninguna etapa de compostaje ni maduración (Lazcano etal., 2008). En otras palabras, al suelo se le agregó un estiércol sin patógenos y seco, en el que el proceso demineralizacióny humificaciónno se había iniciado.

\section{Estabilidad de agregados}

La estabilidad de agregados de los dos suelos tuvo diferencias significativas $(p \leq 0.05)$. Estas diferencias se deben a los distintos contenidos de agentes cementantes que los suelos tuvieron (Cuadro 3), como en el porcentaje de MO en los suelo con y sin enmiendas ( 1.77 y $0.68 \%$, respectivamente) y carbonatos de calcio de 11.6 a $7.6 \%$, aunque la arcilla fue estadísticamente similar en los suelos. De acuerdo con Saleh et al. (2005), la presencia de MO, así como de otros factores minerales como las arcillas silicatadas o carbonatos, pueden influir en la agregación del sueloy su estabilidad. Al respecto, bajo condiciones ambientales de aridez, como en

\section{Characteristics of Solarized manure}

Solarized manure had a Da lower than $1 \mathrm{~g} \mathrm{~cm}^{-3}$, reflecting that the volume occupied by its empty space is greater than its mass, while its $\mathrm{pH}$ (alkaline) and CE (Table 2); can be considered as saline (CNNPAP, 2007).

Cuadro 2. Características del estiércol solarizado. Table 2. Characteristics of Solarized manure.

\begin{tabular}{lcccccc}
\hline $\begin{array}{c}\mathrm{Da}^{*} \\
\left(\mathrm{~g} \mathrm{~cm}^{-3}\right)\end{array}$ & $\begin{array}{c}\mathrm{CE} \\
\left(\mathrm{dS} \mathrm{m} \mathrm{m}^{-1}\right)\end{array}$ & $\mathrm{pH}$ & $\begin{array}{c}\mathrm{MO} \\
(\%)\end{array}$ & $\begin{array}{c}\mathrm{C} \\
(\%)\end{array}$ & $\begin{array}{c}\mathrm{N} \\
(\%)\end{array}$ & $\mathrm{C} / \mathrm{N}$ \\
\hline 0.44 & 7.76 & 8.09 & 29.01 & 16.93 & 0.83 & 20.39 \\
\hline
\end{tabular}

This material had a $\mathrm{C} / \mathrm{N}$ ratio of 20.3 , a result greater than the value 18 , which has been reported for fresh cattle manure (CNNPAP, 2007). While total nitrogen was $0.83 \%$, a lower value than $1.70 \%$ reported for manure (Dominguez, 2009). Solarized manure is the manuere that has been subjected to heat using a plastic cover, in order to eliminate pathogens; however it does not initiate any composting or maturation stage (Lazcano et al., 2008). In other words, the soil was added with dried manure without pathogens, in which a mineralization and humification process was not initiated.

\section{Aggregate stability}

The aggregate stability from the two soils had significant differences $(p \leq 0.05)$. These differences are due to different contents of cementing agents that soils had (Table 3), and the percentage of MO in soils with and without amendments (1.77 and $0.68 \%$, respectively) and calcium carbonate from 11.6 to $7.6 \%$, although clay was statistically similar in both soils. According to Saleh et al. (2005), the presence of MO, as well as other mineral factors such as silicate clays or carbonates, may influence in soil aggregation and stability. In this regard, under environmental conditions of aridity, as in the Comarca Lagunera, aggregate stability depends on the amount and type of mineral cementing agents contained in the soil (Bronick and Lal, 2004). Which was possible to confirm when aggregates stability from $S s$ with different cementing agents, obtaining the following multivariate linear model.

$\mathrm{EA}_{\mathrm{s}}=1.80+0.0753 \mathrm{r}_{\mathrm{s}}-1.57 \mathrm{MO}_{\mathrm{s}}+0.526 \mathrm{CaCO}_{3 \mathrm{~s}}$ 
la Región Lagunera, la estabilidad de los agregados depende de la cantidad y tipo de agentes cementantes minerales que existen en el suelo (Bronick y Lal, 2004). Lo que se pudo constatar cuando se relacionó la estabilidad de los agregados del Ss con los diferentes agentes cementantes, donde se obtuvo el siguiente modelo lineal multivariado

$\mathrm{EA}_{\mathrm{s}}=1.80+0.0753 \mathrm{r}_{\mathrm{s}}-1.57 \mathrm{MO}_{\mathrm{s}}+0.526 \mathrm{CaCO}_{3 \mathrm{~s}}$

Este modelo tiene una $\mathrm{R}^{2}=0.920$, que indica que las variable

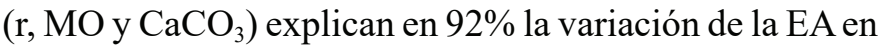
este suelo sin enmiendas. Por otra parte, la probabilidad de rechazo de cada uno de los coeficientes son menores que la propuesta en el análisis ( $p \leq 0.05)$, siendo más significativo para el $\mathrm{CaCO}_{3}(0.001)$; lo cual muestra que los carbonatos tendrían mayor influencia que el resto de los agentes.
This model has a $\mathrm{R}^{2}=0.920$, indicating that variables ( $\mathrm{r}$, MO and $\mathrm{CaCO}_{3}$ ) explain in $92 \%$ EA variation of this soil without amendment. Moreover, the probability of rejection of each of the coefficients is less than the proposal in the analysis ( $p \leq$ $0.05)$, being more significant for $\mathrm{CaCO}_{3}(0.001)$; showing that carbonates would have greater influence than other agents.

By associating carbonates content with aggregate stability, was found that there is a positive trend (Figure 2) which means that if carbonate content increases, aggregate stability under natural conditions will increase at a rate of 0.5117 , although this relationship only explains $77.67 \%$ of the process or phenomenon. Similar results were reported by Virto et al. (2011) and Gargiulo et al. (2013), who reported that the $\mathrm{CaCO}_{3}$ has greater influence on aggregate stability in soils from arid and semiarid regions.

Cuadro 3. Promedios de la estabilidad de agregados, materia orgánica, arcilla y carbonatos de calcio en las muestras de suelo con enmiendas y sin enmienda.

Table 3. Averages of aggregate stability, organic matter, clay and calcium carbonate in soil samples with and without amendment.

\begin{tabular}{|c|c|c|c|c|c|c|c|c|}
\hline \multirow[t]{2}{*}{ Suelo } & \multicolumn{2}{|c|}{ EA* } & \multicolumn{2}{|r|}{ r } & \multicolumn{2}{|c|}{$\mathrm{MO}$} & \multicolumn{2}{|c|}{$\mathrm{CaCO}_{3}$} \\
\hline & $\overline{\mathrm{X}}$ & $\overline{\mathrm{X}} \pm \sigma$ & $\overline{\mathrm{X}}$ & $\overline{\mathrm{X}} \pm \sigma$ & $\bar{X}$ & $\overline{\mathrm{X}} \pm \sigma$ & $\bar{X}$ & $\overline{\mathrm{X}} \pm \sigma$ \\
\hline & \multicolumn{8}{|c|}{ 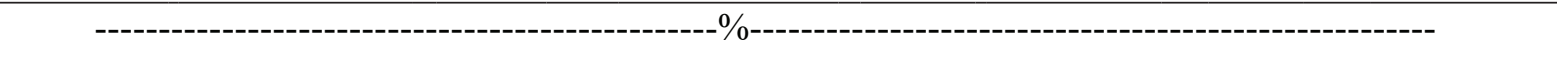 } \\
\hline Ss & $8.2 \mathrm{~b}$ & $6.6-8.7$ & $18.7 \mathrm{a}$ & $14.7-22.7$ & $0.7 \mathrm{~b}$ & $0.5-0.9$ & $11.6 \mathrm{a}$ & $10.7-12.5$ \\
\hline $\mathrm{Se}$ & $11.6 \mathrm{a}$ & $11.1-12.1$ & $19.0 \mathrm{a}$ & $14.9-23.1$ & $1.8 \mathrm{a}$ & $1.6-2.0$ & $7.6 \mathrm{~b}$ & $7.3-7.9$ \\
\hline DMS & 0.8 & & 3.1 & & 0.1 & & 0.52 & \\
\hline
\end{tabular}

Al relacionar el contenido de carbonatos con la estabilidad de agregados se encontró que existe una tendencia positiva (Figura 2) lo que significa que si el contenido de carbonato se incrementa una unidad, la estabilidad de agregados en condiciones naturales se incrementara a razón de 0.5117 , aunque esta relación sólo explica $77.67 \%$ del proceso o fenómeno. Resultados similares fueron reportados por Virto et al. (2011) y Gargiulo et al. (2013), quienes reportaron que el $\mathrm{CaCO}_{3}$ tiene mayor influencia en la estabilidad de agregados en suelos de regiones áridas y semiáridas.

En cambio, la estabilidad de agregados (11.6\%) en el suelo que recibió enmiendas orgánicas en forma de estiércol solarizado, fue estadísticamente diferente $(p \leq 0.05)$ y mayor que en los suelos dónde no se aplicó estiércol (Cuadro 3), de tal manera que su estabilidad se incrementó $41.4 \%$. El modelo de la relación entre la estabilidad y las variables en este suelo fue el siguiente.

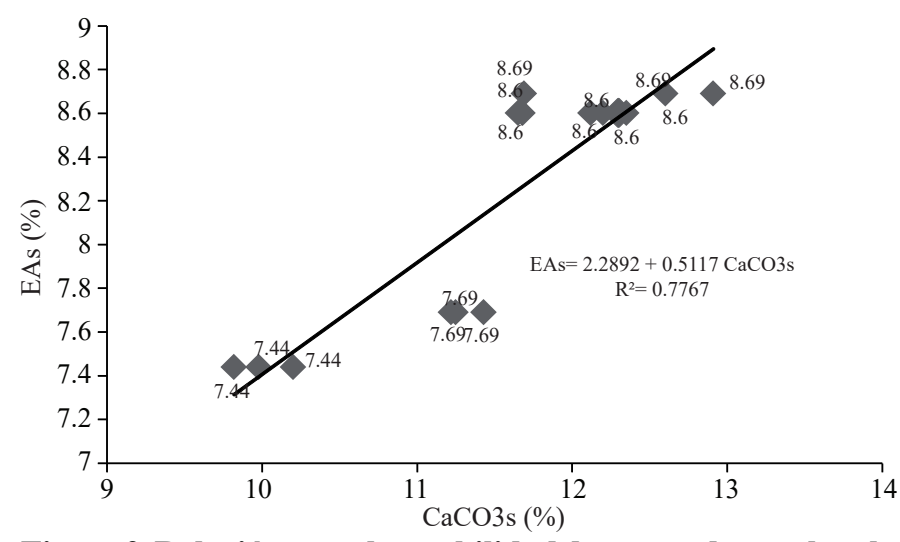

Figura 2. Relación entre la estabilidad de agregados en el suelo sin enmiendas y el contenido de $\mathrm{CaCO}_{3}$.

Figure 2. Relationship between aggregate stability in soils without amendments and $\mathrm{CaCO}_{3}$ content.

Instead, aggregate stability (11.6\%) on soils that received organic amendments as solarized manure was statistically different $(p \leq 0.05)$ and higher than in soils where manure 
$\mathrm{EA}_{\mathrm{e}}=8.40+0.0861 \mathrm{r}_{\mathrm{e}}+8.89 \mathrm{MO}_{\mathrm{e}}-0.526 \mathrm{CaCO}_{3 \mathrm{e}}$

Donde las variables ( $\mathrm{r}, \mathrm{MO}$ y $\mathrm{CaCO}_{3}$ ) intervienen en el comportamiento de esta estabilidad en $91.4 \%$. No obstante, al analizar la probabilidad de rechazo de cada una de las variables (Cuadro 4), la $\mathrm{MO}_{\mathrm{e}}$ fue la única que tuvo una probabilidad de rechazo (0.010) menor que $p$. Esto indica que si solo se considera a la $\mathrm{MO}_{\mathrm{e}}$ como variable independiente en el comportamiento de la $\mathrm{AS}_{\mathrm{e}}$, sería más conveniente. was not applied (Table 3), meaning an increase in its stability $41.4 \%$. The model of the relationship between stability and variables in this soil was the following:

$\mathrm{EA}_{\mathrm{e}}=8.40+0.0861 \mathrm{r}_{\mathrm{e}}+8.89 \mathrm{MO}_{\mathrm{e}}-0.526 \mathrm{CaCO}_{3 \mathrm{e}}$

Where variables (r, $\mathrm{MO}$ and $\mathrm{CaCO}_{3}$ ) involved in the behavior of this stability in $91.4 \%$; however, when analyzing the probability of rejection of each of the variables (Table 4),

Cuadro 4. Análisis de varianza de los modelos multivariados de la estabilidad de agregados con y sin enmiendas. Table 4. Analysis of variance of the multivariate models of aggregate stability with and without amendments.

\begin{tabular}{llllll}
\hline Suelo & Predictor & Coeficientes & $\mathrm{SE}$ & $\mathrm{T}$ & $\mathrm{p}$ \\
\hline Suelo sin enmienda & Constante & 1.797 & 0.602 & 2.99 & 0.012 \\
& $\mathrm{r}_{\mathrm{s}}$ & 0.0753 & 0.020 & 3.71 & 0.003 \\
& $\mathrm{MO}_{\mathrm{s}}$ & -1.570 & 0.415 & -3.78 & 0.003 \\
& $\mathrm{CaCO}_{3 \mathrm{~s}}$ & 0.525 & 0.049 & 10.52 & 0.001 \\
Suelo con enmienda & $\mathrm{Constante}$ & 8.404 & 5.180 & 1.45 & 0.176 \\
& $\mathrm{r}_{\mathrm{e}}$ & 0.0861 & 0.0983 & 0.88 & 0.400 \\
& $\mathrm{MO}_{\mathrm{e}}$ & 8.889 & 2.866 & 3.10 & 0.010 \\
& $\mathrm{CaCO}_{3 \mathrm{e}}$ & -1.877 & 1.052 & -1.78 & 0.102 \\
\hline
\end{tabular}

$\overline{\mathrm{SE}}=$ suma del error; $\mathrm{T} \mathrm{t}$ de tablas; $p$ : probabilidad de rechazo $\leq 0.05$.

Al relacionar el contenido de $\mathrm{MO}_{\mathrm{e}}$ con la estabilidad de agregados en el suelo con enmiendas, se tuvo una tendencia positiva (Figura 3 ) lo que significa que al incrementarse en una unidad el contenido de MO, la estabilidad se incrementaría 8.4715 veces. Lo anterior es consistente con lo que mencionan Lazcano et al. (2008), ya que ellos indican que la acumulación de $\mathrm{MO}$ en los primeros centímetros de suelo, promueve la estabilidad de los agregados y por ende la agregación de los suelos.

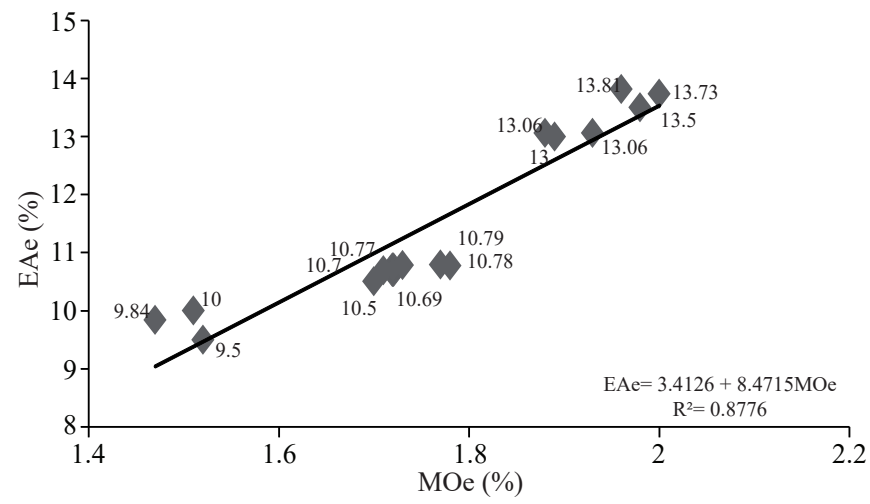

Figura 3. Relación entre la estabilidad de agregados en el suelo con enmiendas y el contenido de materia orgánica.

Figure 3. Relationship between soil aggregate stability with amendments and organic matter content.
MOe was the only one that had a probability of rejection $(0.010)$ less than $p$. This indicates that if only considers MOe as an independent variable in the behavior of the $A S e$, it would be more convenient.

By relating MOe content with aggregate stability in the soil with amendments, there was a positive trend (Figure 3 ) which means that by increasing in a unit MO content, stability will increase 8.4715 times. This is consistent with Lazcano et al. (2008), who indicate that the accumulation of MO in the top few centimeters of soil, promotes aggregate stability and thus soil aggregation.

However, the stability of the soil (with and without amendments) is very low ( $<30 \%)$, according to what Lobo and Pulido (2006) established; also, the quality of the structure of these soils is poor, considering the criteria proposed by Alvear et al. (2007). Similar results were reported by Pagliai et al. (2004), who indicate that physical degradation of the soil is related to human activity or soil management. Also, Mikha and Rice (2004) when analyzing soil structure after adding $\mathrm{MO}$, found that conventional tillage resulted in the loss of $\mathrm{MO}$ and therefore a poor soil structure. Therefore, it is likely that the behavior found in 
No obstante, la estabilidad de los suelos (con y $\sin$ enmiendas) es muy baja $(<30 \%)$, de acuerdo a lo que establecieron Lobo y Pulido (2006); asimismo, la calidad de la estructura de estos suelos es pobre, al considerar los criterios propuestos por Alvear et al. (2007). Resultados similares fueron reportados por Pagliai et al. (2004), quienes indican que la degradación física del suelo está relacionada a la actividad humana o el manejo que tenga el suelo. Asimismo, Mikha y Rice (2004) al analizar la estructura del suelo después de agregar MO, encontraron que la labranza convencional provocaba la pérdida de $\mathrm{MO}$ y por ende una pobre estructura del suelo. Por lo anterior, es probable que el comportamiento que se encontró en este estudio, haya sido consecuencia de la dosis y el número de aplicaciones que se dieron al suelo; de tal manera que si se aumentara la dosis y el número de aplicaciones, la estabilidad se incrementaría.

Alagöz y Yilmaz (2009) indican que la efectividad de las enmiendas orgánicas depende del número y la frecuencia de sus aplicaciones; así como del manejo de los suelos que reciben estos materiales, puesto que se incrementa la estabilidad de los agregados y se mantienen las reservas de carbono en el suelo (Yang et al. 2007). Aunque, el uso indebido del suelo por la labranza, puede provocar una disminución en el contenido de MO en el suelo (Weil y Magdoff, 2004). Al considerar los resultados que se obtuvieron en este estudio, se observa que la estabilidad de agregados no fue la esperada, aunque se presentó un ligero incremento en la estabilidad del suelo que recibió enmiendas, comportamiento que se puede explicar por tres situaciones, la primera es la calidad del estiércol solarizado que es menor que la de otros estiércoles, por otra parte está el tipo de suelo de la región (condiciones climáticas) y por la actividad a la que se dedican estos suelos.

\section{Conclusiones}

Uno de los suelos agrícolas que se encuentran en la Región Lagunera de Coahuila México se clasificó como Fluventic haplocambids con Taxonomía de Suelos. Estos suelos se caracterizan por sus bajos contenidos de MO (0.68\%) y porque se utilizan en un sistema de producción agrícola extensivo. Aun cuando en este suelo se han aplicado enmiendas orgánicas de estiércol solarizado por más de this study, was the consequence of the dose and number of applications that were given to the soil; such that if dose and the number of applications increases, the stability would increase.

Alagöz and Yilmaz (2009) indicate that the effectiveness of organic amendments depends on the number and frequency of their applications; as well as soil management, since aggregate stability increases and carbon stocks remain in the soil (Yang et al., 2007). Although, the misuse of soil tillage can cause a decrease of MO content in the soil (Weil and Magdoff, 2004); considering the results obtained in this study, it is observed that aggregate stability was not the expected, although there was a slight increase in soil stability on soil with amendments, behavior that can be explained by three situations, first solarized manure quality was lower than other manures, second the soil type in the region (climatic conditions) and third land use.

\section{Conclusions}

One of the agricultural soils found in the Comarca Lagunera from Coahuila Mexico was classified as Fluventic Haplocambids through Soil Taxonomy. These soils are characterized by low MO contents $(0.68 \%)$ and because they are used on an extensive agricultural production system. Although in this soil has been applied organic solarized manure amendments for more than eight years, the content of organic matter is $1.77 \%$. Moreover, aggregates stability in soils of this study is low or bad. Although, stability depends on soil management; ie, soil where solarized manure was applied had a slight increase on aggregates stability (11.6\%); however, when the soil does not receive organic amendments, stability is determined by calcium carbonate. It is likely that actions set to improve the quality of solarized manure, such as composting or mixture of different organic materials with it, contribute to its effect on the physical conditions of the soils. However, more research is required where the quality of organic material and characteristics of soil management are considered.

End of the English version

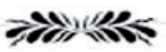


ocho años, el contenido de materia orgánica sólo llega a ser de $1.77 \%$. Por otra parte, la estabilidad de los agregados en los suelos de este estudio es baja o mala. Aunque, la estabilidad depende del manejo que se le haya dado al suelo; es decir, el suelo donde se aplicó estiércol solarizado tuvo un ligero incremento en la estabilidad de sus agregados (11.6\%); en cambio, cuando el suelo no recibe enmiendas orgánicas la estabilidad está determinada por los carbonatos de calcio. Es probable que acciones encaminadas a mejorar la calidad del estiércol solarizado, como el compostaje o la mezcla de diferentes materiales orgánicos con éste, contribuyan en su efecto en las condiciones físicas de los suelos. Sin embargo, se requiere de mayor investigación donde se involucren la calidad del material orgánico y las características del laboreo constante.

\section{Literatura citada}

Alagöz, Z. and Yilmaz, E. 2009. Effects of different sources of organic matter on soil aggregate formation and stability: a laboratory study on a Lithic Rhodoxeralf from Turkey. Soil Tillage Res. 103:419-424.

Alvear, M.; Reyes, F.; Morales, A.; Arriaga, C. y Reyes, M. 2007. Actividad biológica y agregados estables al agua en dos tipos de formaciones vegetales de un bosque templado del Centro-Sur de Chile con perturbaciones antrópicas. Ecología Austral. 17:113-122.

Arroita, M.; Causapé, J.; Comín, F. A.; Díez, J.; Jimenez, J. J.; Lacarta, J.: Lorente, C.; Merchán, D.; Muñiz, S.; Navarro, E.; Val, J. and Elosegi, A. 2013. Irrigation agriculture affects organic matter decomposition in semi-arid terrestrial and aquatic ecosystems. J. Hazardous Materials. 263:139-145.

Bastida, F.; Jindo, K.; Moreno, J. L.; Hernández, T. and García, C. 2012. Effects of organic amendments on soil carbon fractions, enzyme activity and humus-enzyme complexes under semi-arid conditions. Eur. J. Soil Biol. 53:94-102.

Bronick, C. J. and Lal, R. 2004. Soil structure and management: a review. Geoderma. 124:3-22.

CTNNPAP (Comité Técnico de Normalización Nacional de Productos Agrícolas y Pecuarios). 2007. Humus de lombriz (Lombricomposta) especificaciones y métodos de prueba. NMX-FF-109-SCF. México, D F. 325 p.

Domínguez, G. F.; Diovisalvi, N. V.; Studdert, G. A. and Monterubbianesi, M. G. 2009. Soil organic C and N fractions under continuous cropping with contrasting tillage systems on mollisols of the southeastern pampas. Soil Tillage Res. 102:93-100.

Fortis, H. M.; Leos, R. J. A.; Orona, C. I.; García, H. J. L.; Salazar, S. E.; Preciado, R. P.; Orozco, V. J. A. y Segura, C. M. A. 2009. Uso de estiércol en la Comarca Lagunera. In: Orona, C. I; Salazar, S. E.; Fortis, H. M.; Trejo, E. H. I. y Vázquez, V. V.(Eds). Libro de agricultura orgánica. FAZ-UJED, Gómez Palacio, Durango. México. 104-127 pp.
García, H. J. L.; Valdez, C. R. D.; Servín, V. R.; Murillo, A. B.; Rueda, P. E. O.; Salazar, S. E.; Vázquez, V. C. and Troyo, D. E. 2009. Pest management in organic vegetable production. Tropical and Subtropical Agroecosystems. 10:15-29.

García, E. 1988. Modificaciones al sistema de clasificación climática de Köppen. Ind, México, D.F.

Gargiulo, L.; Mele, G. and Terribile, F. 2013. Image analysis and soil micromorphology applied to study physical mechanisms of soil pore development: an experiment using iron oxides and calcium carbonate. Geoderma. 197-198:151-160.

Hernández, O. G.; Segura, C. M. A.; Álvarez, G. L. C.; Aldaco, N. R. A.; Fortis, H. M. y González, C. G. 2013. Comportamiento del arsénico en suelos de la región Lagunera de Coahuila, México. Terra Latinoam. 31:295-303.

Huang, P. M.; Li, Y. and Sumner, M. E. 2011. Handbook of soil sciences: properties and processes. Second Edition. CRC Press, Boca Raton, Fl, USA. 45 p.

Lazcano, C.; Gómez, B. M. and Domínguez, J. 2008. Comparison of the effectiveness of composting and vermicomposting for the biological stabilization of cattle manure. Chemosphere. 72:1013-1019.

Lobo, D. y Pulido, M. 2006. Métodos e índices para evaluar la estabilidad estructural de los suelos. Universidad Central de Venezuela, Facultad de Agronomía, Instituto de Edafología. Caracas, Venezuela. $185 \mathrm{p}$.

López, M. J. D.; Salazar, S. E.; Trejo, E. H. I.; García, H. J. L.; Navarro, M. M.y Vázquez, V.C. 20014. Producción de algodón con altas densidades de siembra usando fertilización orgánica. Rev. Int. Bot. Exp. Phyton. 83:237-242.

Lozano,Z.; Rivero, C.; Bravo, C. y Hernández, H. R. M. 2011. Fracciones de la materia orgánica del suelo bajo sistemas de siembra directa y cultivos de coberturas. Rev. Fac. Agron. 28:35-56.

Mikha, M. M. and Rice, W. 2004. Tillage and manure effects on soil and aggregate-associated carbon and nitrogen. Soil Sci. Soc. Am. J. 68:809-816.

Minitab Inc ${ }^{\circledR}$. 2013. Minitab Inc. Pine Hall Rd State College. USA, PA.

Plagiai, M.; Vignozzi, N. and Pellegrini, S. 2004. Soil structure and the effect of management practices. Soil Tillage Res. 79:131-143.

Porta, C. J.; Poch, R. M. y López, A. M. Y. 2010. Introducción a la Edafología: uso y protección del suelo. Mundi-Prensa. México, D. F. 76 p.

Prieto, M. J.; Prieto, G. F.; Acevedo, S. O. A. y Méndez M., M. A. 2013. Indicadores e índices de calidad de los suelos (ICS) cebaderos del sur del estado de hidalgo, México. Agron. Mesoam. 24:83-91.

Ruíz, F. J. F. 2011. Ingeniería del compostaje. Universidad Autónoma Chapingo (UACH). Chapingo, Estado de México. 33 p.

Saleh, N.; Phenrat, T.; Sirk, K.; Dufour, B.; Ok, J. and Sarbu, T. 2005. Adsorbed triblock copolymers deliver reactive iron nanoparticles to the oil/water interface. Nano Lett. 5:24892494.

SSI (Soil Survey Investigations). 2009. Soil survey laboratory methods manual. Report. No. 42 Version 3.0. United State Department of Agriculture. Natural Resources Conservation Service. National Soil Survey Center. USA, Washington, D.C.

SSS (Soil Survey Staff). 2014. Keys to soil taxonomy, 12 $2^{\text {th }}$ (Ed.): USDA-Natural resources conservation service. Washington, D. C. 325 p. 
Trejo, E. H. I.; Salazar, S. E.; López, M. J. D. y Vázquez, V. C. 2013. Impacto del estiércol bovino en el sueloy producción de forraje de maíz. Rev. Mex. Cienc. Agríc. 4:727-738.

Van Reeuwijk, L. P. 2006. Procedures for soil analysis. $7^{\text {th }}$ (Ed.). Tech. Pap. 9. ISRIC-world soil information. Wageningen, Netherlands. $87 \mathrm{p}$

Verdonk, O. and Demeyer, P. 2004. The Influence of the particle sizes on the physical properties of growing media. Acta Hort. 644:99-101.

Virto, I.; Gartzia, B. N. and Fernández, U. O. 2011. Role of organic matter and carbonates in soil aggregation estimated using laser diffractometry. Pedosphere. 21:566-572.
Weil, R. R. and Magdoff, F. 2004. Significance of soil organic matter to soil quality and health. In: Magdoff, F. and Weil, R. R. eds. Soil organic matter in sustainable agriculture. CRC Press, Boca Raton, FL, USA. 1 p.

Yang, Z. H.; Singh, B. R. and Hansen, S. 2007. Aggregate associated carbon, nitrogen and sulfur and their ratios in longterm fertilized soils. Soil Tillage Res. 95:161-171.

Zhang, W.; Rattanaudompol, U.; Li, H. adn Bouchard, D. 2013. Effects of humic and fulvic acids on aggregation of aqu/nC60 nanoparticles. Water Res. 47:1793-1802. 